\title{
VARIABILITY OF YIELD TRAITS AND DISEASE RESISTANCE IN WINTER TRITICALE GENETIC RESOURCES ACCESSIONS
}

\author{
Wanda Kociuba, Aneta Kramek \\ Institute of Genetics, Breeding and Plant Biotechnology, University of Life Sciences \\ ul. Akademicka 15, 20-950 Lublin, Poland \\ e-mail: wanda.kociuba@up.lublin.pl; aneta.kramek@up.lublin.pl
}

Received: 30.04.2014

\begin{abstract}
A systematic gathering of winter triticale accessions was started in Poland in 1982 by the Institute of Genetics, Breeding and Seed Science at the Agricultural University in Lublin (at present its name is: Institute of Genetics, Breeding and Plant Biotechnology at the University of Life Sciences in Lublin). First, breeding lines obtained in local breeding stations were gathered. Next, accessions were imported from the following world gene banks: Beltsville, Gatersleben, and VIR. Interesting hybrid materials obtained in research centers were also included in the collection. Now, the collection includes 2349 accessions (1329 of winter triticale and 1020 of spring triticale). The evaluation is conducted in a 4-year cycle of field experiments using the same methods. The gathered accessions represent a large range of variability of both morphological and commercial traits. The large differentiation of accessions especially concerns traits such as: plant height, number and weight of grains per spike, protein content in grain, field resistance to powdery mildew, brown rust and leaf and spike diseases.
\end{abstract}

Key words: collection of triticale, spike diseases, genetic resources, fungal diseases, variability, yield traits

\section{INTRODUCTION}

Triticale ( $\times$ Triticosecale Wittm. ex A. Camus) is a man-made cereal crop developed around 1870 in Scotland. It was derived from intergeneric crosses between the female parent wheat (Triticum ssp.) and the male parent rye (Secale ssp.). Recent breeding and research efforts, however, have mainly focused on improving hexaploid triticale $[1,2]$. Triticale is uniquely different from other cereals in nutritional quality and broader adaptability. It also has a higher yield potential, is generally more competitive with weeds than wheat and displays better tolerance to drought and pests than its ancestral species [1, 3, 4].
Knowledge of genetic diversity and variation of initial material provides a better insight in selecting parents in a breeding program in terms of identifying diverse accessions for traits of adaptation and productivity [5-7]. Genetic diversity of initial material is the basic condition for improvement of crop plants, including triticale. Progress in the breeding of new cultivars of this cereal depends mainly on the choice of appropriate forms for crossbreeding. Consequently, it is necessary to collect and protect both new and old accessions to be used for plant breeding and research as valuable sources of genetic variability for important useful traits [8-11].

The research and collection of hybrid materials of triticale was started in Poland in 1982 by the Institute of Genetics, Breeding and Seed Science at the Agricultural University in Lublin (at present its name is: Institute of Genetics, Breeding and Plant Biotechnology at the University of Life Sciences in Lublin). The basic aim of this research has been to collect registered cultivars, cultivars deleted from the register and valuable breeding materials on a regular basis. The accessions that constitute the subject of research come from Polish and foreign breeding centres and from gene banks located all over the world. The collections of winter and spring triticale genetic resources, just like collections of other plants, are assessed and described; they also undergo standard observations and their important commercial traits are measured. In this way a new variation can be defined [9-15]. After the evaluation has been completed, the accessions are sent to an air-conditioned storage facility of IHAR (Plant Breeding and Acclimatization Institute) in Radzików so as to ensure the availability of a suitable amount of grain for cultivation and exchange with other gene banks. At present, 1329 winter triticale and 1020 spring triticale accessions have been gathered in the storage facility. $52 \%$ 
of winter triticale accessions and $72 \%$ of spring triticale accessions are foreign forms and respectively $40 \%$ and $7 \%$ are materials of Polish origin (Fig. 1).

The aim of this study was to characterize the collection of winter triticale ( $\times$ Triticosecale Wittm. ex A. Camus) genetic resources collected in the Polish Gene Bank in terms of yield traits and field resistance to fungal diseases. In this paper, the variability of genetic resources of triticale originated from different regions of the world under soil and climatic conditions of Poland was also assessed. The presented results may constitute a source of valuable information for breeders about the range of variability of the analysed parameters, which will facilitate the selection of interesting accessions as initial materials for the relevant breeding programs.

\section{MATERIALS AND METHODS}

The research material consisted of 1329 hexaploid winter triticale accessions originated from different regions of the world. $52 \%$ of them were foreign forms, $40 \%$ were materials of Polish origin and $8 \%$ were of unknown origin (Fig. 1).

Each accession was examined in a four-year cycle of non-replicated field experiments with no standard, on the basis of uniform assessment and measurement methodology. Three time intervals were taken into consideration: 1982-1990 (565 accessions were analysed), 1991-2000 (561 accessions were analysed), 2001-2010 (203 accessions were analysed). Each year, the collection of triticale genetic resources was expanded with newly added accessions which began the next four-year cycle. Thus, the number of accessions varied in the particular years.

The experiments were carried out at the Experimental Field Station of the University of Life Sciences in Lublin in Czeslawice near Nałęczów, in the Lublin Upland, on brown loess soil. Each year, seeds were sown by hand in $2 \mathrm{~m}^{2}$ plots with rows $20 \mathrm{~cm}$ apart and seed spacing of about $2 \mathrm{~cm}$. Due to the partial allogamy, which occurs in triticale after spike formation, some spikes were isolated from the rest (by means of 2 or 3 cellophane isolators in each plot) to preserve the identity of the accessions. The isolated spikes were harvested separately and the grain was used for sowing in the next growing season.

In each growing season, field observations of the major phenological plant stages, such as sprouting, heading and full maturity, were performed. Moreover, assessment of sprouting, overwintering, lodging and plant resistance to fungal diseases was carried out on the basis of a 9-point scale according to COBORU (Research Centre for Cultivar Testing). In this scale, 9 means the most advantageous condition from the agricultural point of view, whereas mark: 1 - the least advantageous. Plant height was also measured in 3 places in each plot.

When the plants reached full maturity, 50 spikes from each accession were selected at random. Then, spike length and number of spikelets per spike were determined on the basis of 20 spikes. The number and weight of grains per spike as well as 1000-grain weight (TGW) were determined on the basis of 50 spikes. The protein content in grain was determined by the Kjeldahl method with a Kjeltec analyzer (FOSS) in the Central Agroecology Laboratory of the University of Life Sciences in Lublin, using a conversion factor N'5.7.

The presented results include the multi-year mean value and the range of variability as well as the variation coefficients of important agricultural traits and the estimation of field resistance to fungal diseases in the collection of winter triticale genetic resources obtained in: 1982-1990, 1991-2000, 2001-2010.

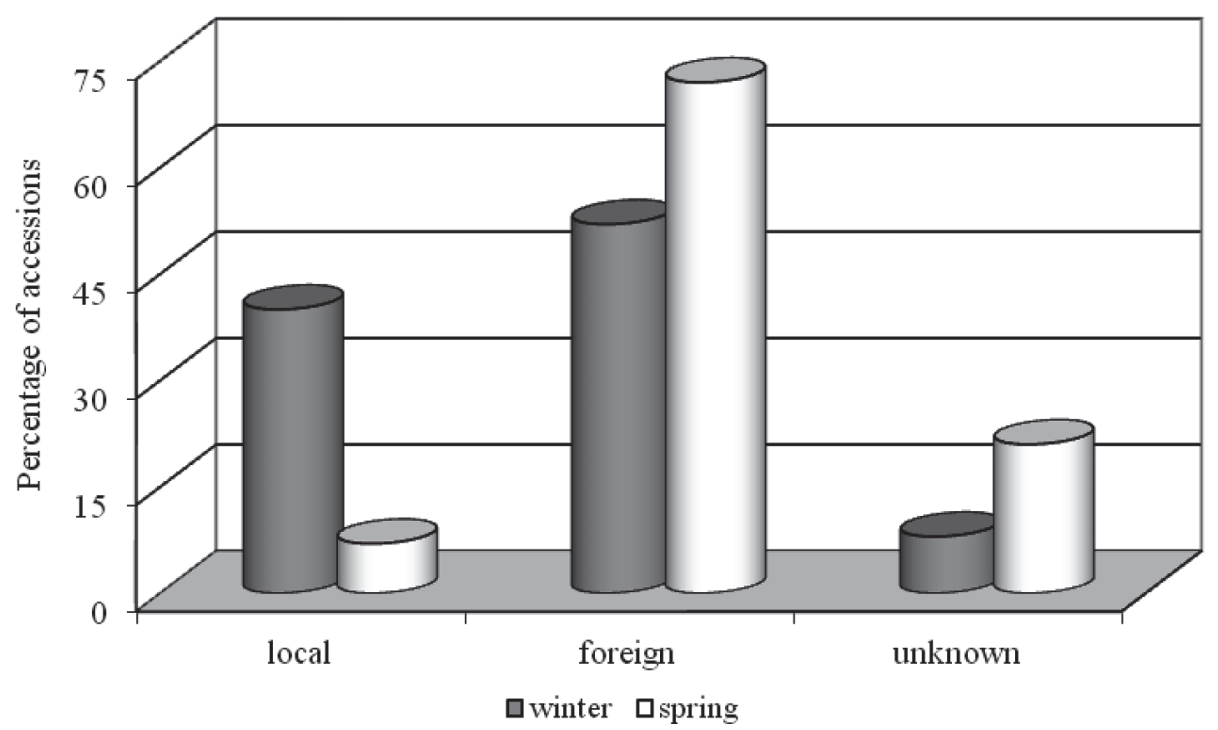

Fig. 1. The origin of collected winter and spring triticale genetic resources accessions. 


\section{RESULTS}

The data presented in Table 1 show that the collection of winter triticale genetic resources was characterised by a wide variability of the yield traits analysed. The greatest variability observed during the time of the experiments related to the number and weight of grains per spike. The range of variability of these traits between 1982 and 2010 was from 14.0 to 85.1 as far as the number of grains per spike is concerned and from 0.4 to $6.8 \mathrm{~g}$ for the weight of grains per spike. The variation coefficients of the above-mentioned traits were the highest during the first years of the collection (1982-1990), which showed a greater diversity of older triticale accessions. Throughout the period of the experiments in the analysed population of winter triticale, the weight of grains per spike ranged from 2.1 to $2.5 \mathrm{~g}$ in the largest number of accessions (Fig. 2). Moreover, the share of accessions with the weight of grains per spike exceeding $3.0 \mathrm{~g}$ was higher in the accessions examined after 1991, which showed that the selection of breeding material significantly affected yield-contributing traits.

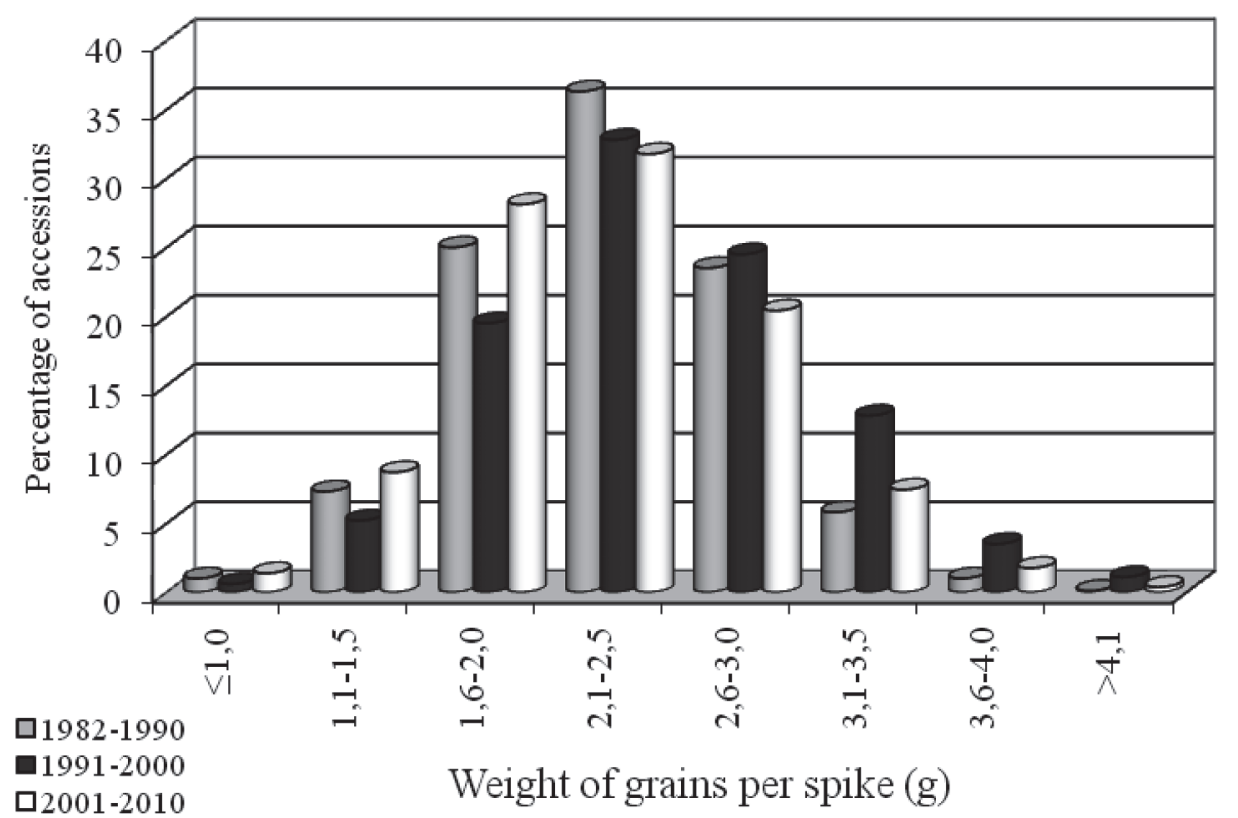

Fig. 2. The distribution of weight of grains per spike in the collection of winter triticale genetic resources.

1000 grain weight (TGW) was another important element for breeding, since it provides information not only about the quantity of crop but also about its quality. The production yield of a cultivar depended on high TGW, a high number and weight of grains per spike and appropriate density of spikes per unit area. In the examined collection of winter triticale genetic resources, the weight of 1000 grains ranged from 25.4 to $86.2 \mathrm{~g}$, and most of the accessions had TGW from 45.0 to $55.0 \mathrm{~g}$ (Table 1, Fig. 3). Therefore, valuable accessions were the ones in which the value of the trait in question exceeded $60 \mathrm{~g}$.

A decrease in protein content in triticale grain was also observed in the investigated collection resources. The mean protein content in grain of winter triticale genetic resources examined between 1982 and 1990 was $15.1 \%$, while between 2001 and $2010-10.5 \%$. It needs to be stressed that in the collected accessions this trait showed a wide range of variability (from 5.9 to $19.3 \%$ ), irrespective of the time of the experiments.
Moreover, the variation coefficient for grain protein content ranged from $8.6 \%$ (1991-2000) to $13.1 \%$ (1982-1990) and it showed a decreasing tendency not only in the genetic resources of winter triticale, but also in triticale breeding (Table 1, Fig. 4).

The height of winter triticale plants was varied throughout the experiments (ranging from 70.0 to $172.0 \mathrm{~cm}$ ), which was associated with the introduction to the collection of new cultivars and older ones from world collections (Table 1, Fig. 5). The accessions of winter triticale analysed between 1982 and 1990 were the highest $(128.5 \mathrm{~cm})$. In the following years, the plant height dropped to $110 \mathrm{~cm}$, which was caused by the introduction of semi-dwarf cultivars of this crop.

Among 330 accessions examined between 1985 and 1988 , over $92 \%$ showed very good resistance to powdery mildew (score 9) and 63.9\% did not manifest any signs of being affected with brown rust. Between 2001 and 2010, a decrease in field resistance to the above-mentioned disease-generating factors was observed as 
compared to the previous examination time. Accessions resistant to powdery mildew and brown rust constituted $78.9 \%$ and $53.1 \%$, respectively, of the investigated population (Fig. 6, 7). The high susceptibility to leaf and spike diseases caused by the fungus Stragonospora nodorum was and still is a big problem in the case of triticale. As the data presented in Fig. 8 show, older accessions of winter triticale showed a higher resistance to this pathogenic factor (scores 6 and 7; 40.3\% and 16.7\%, respec- tively) as compared to the latest resources; only $29.8 \%$ of them received a score of 6 , whereas $11.2 \%$ a score of 7. Resistant accessions, which were a valuable source of resistance, constituted a small percentage both among the older and younger genotypes. Thanks to large-scale breeding work, many forms of triticale resistant to the particular pathogens have been obtained, but the genotypes that exhibited a complex resistance to diseases were the most valuable from the point of view of agriculture.

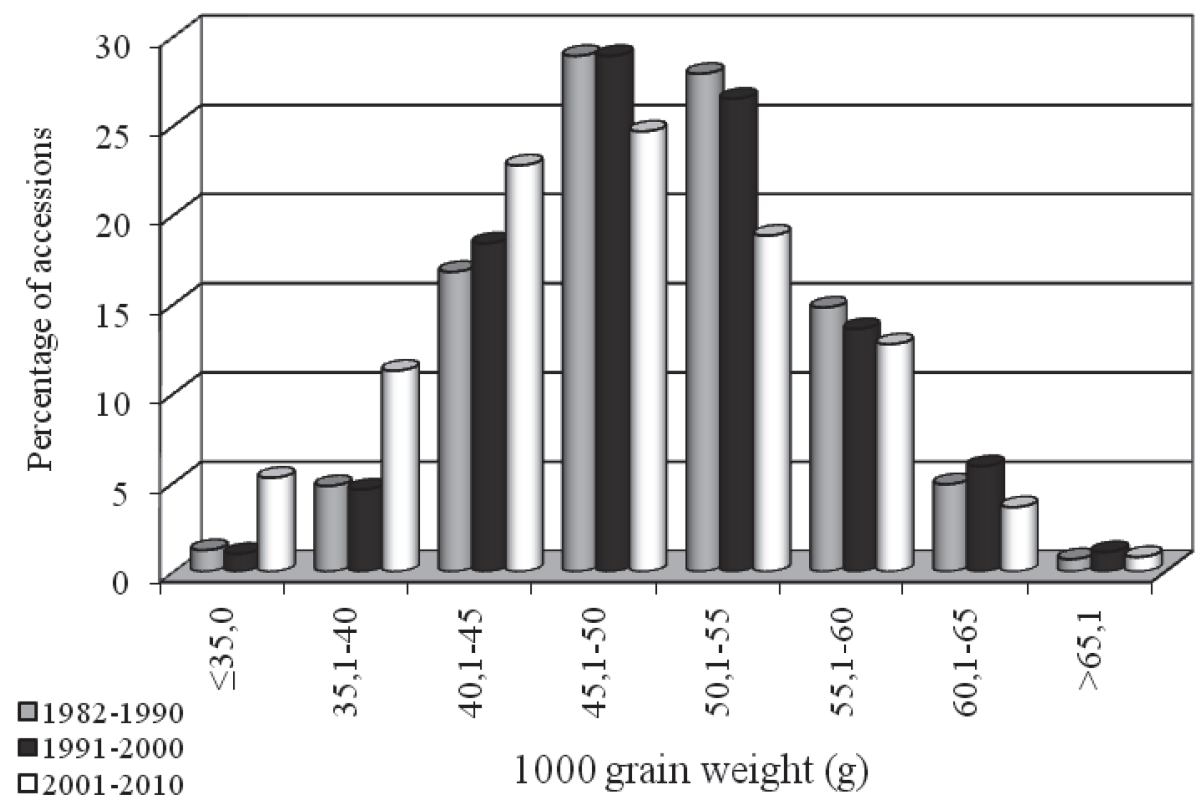

Fig. 3. The distribution of 1000 grain weight in the collection of winter triticale genetic resources.

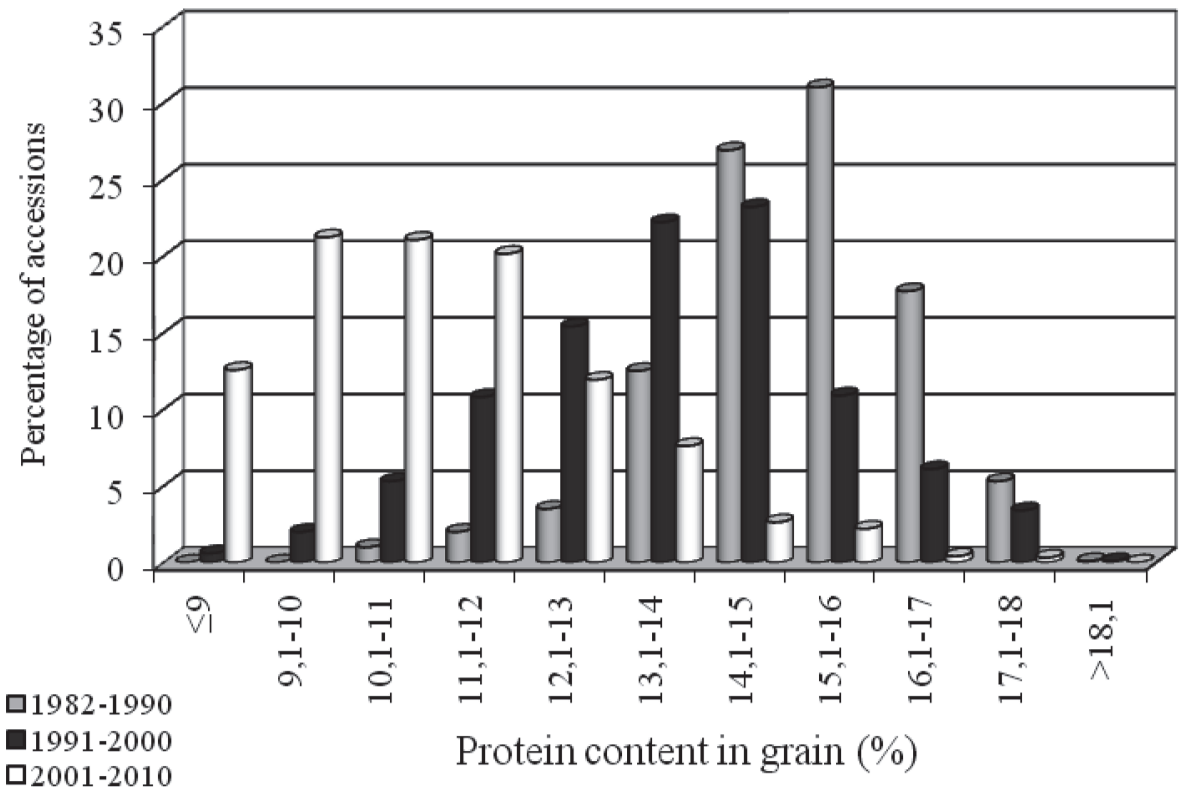

Fig. 4. The distribution of protein content in grain in the collection of winter triticale genetic resources. 


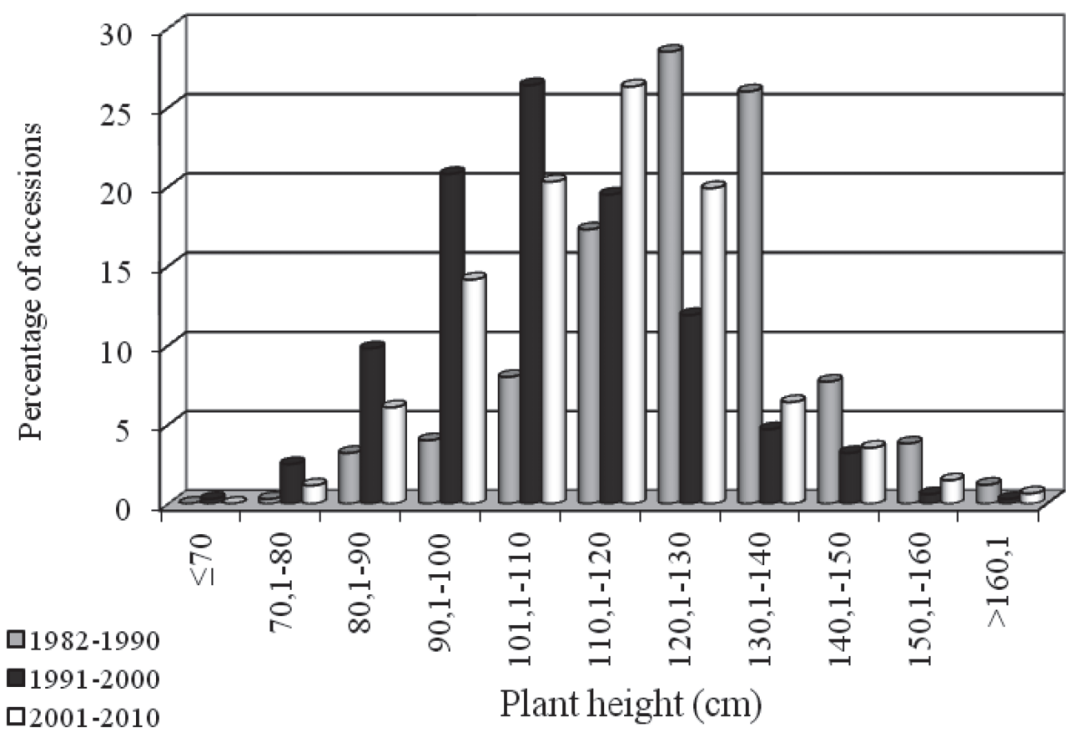

Fig. 5. The distribution of plant height in the collection of winter triticale genetic resources.

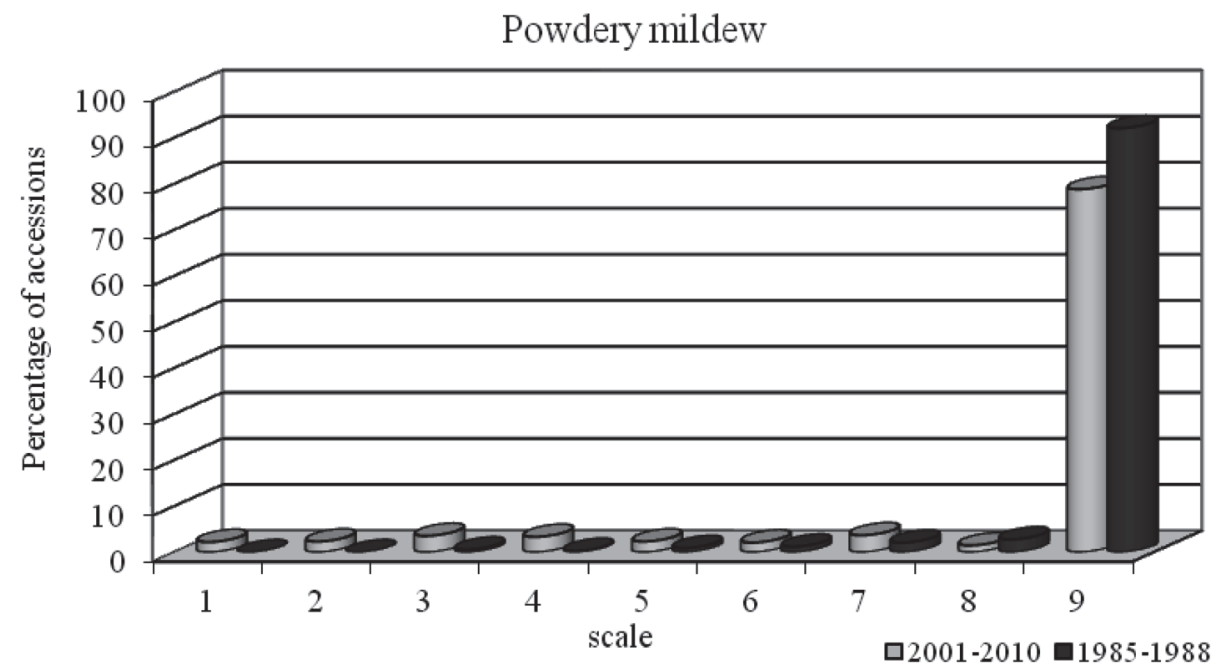

Fig. 6. The distribution of infection by powdery mildew in the collection of winter triticale genetic resources.

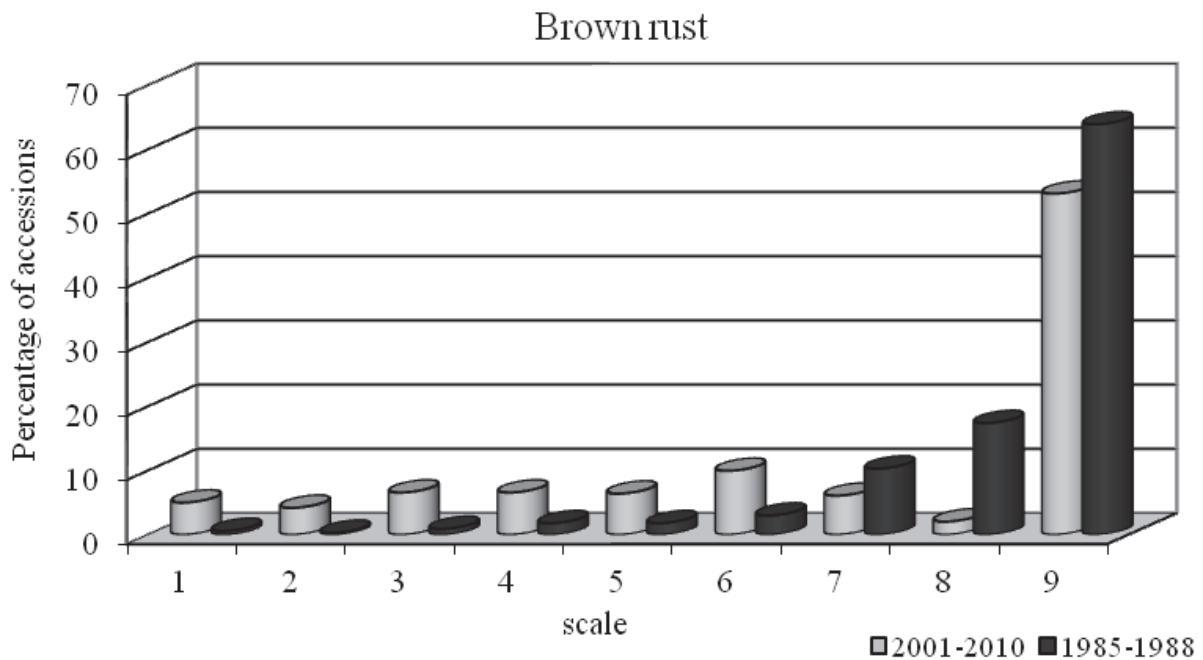

Fig. 7. The distribution of infection by brown rust in the collection of winter triticale genetic resources. 


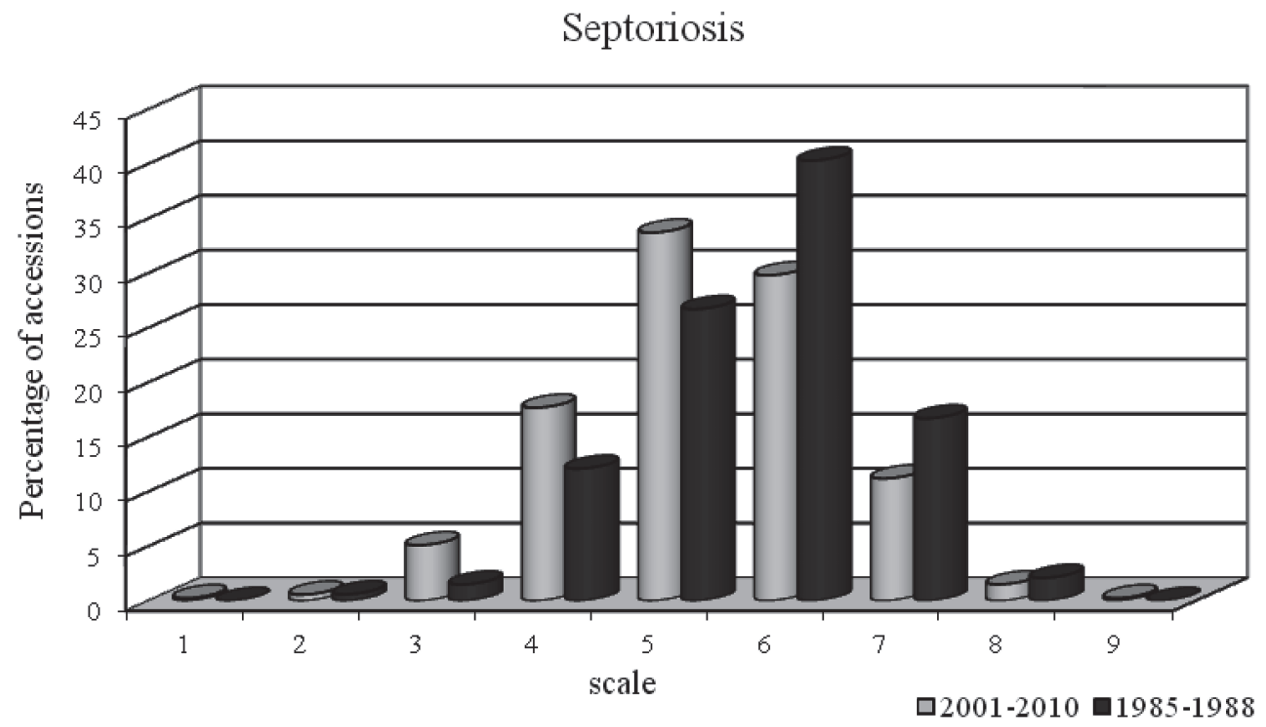

Fig. 8. The distribution of infection by septoriosis in the collection of winter triticale genetic resources.

Table 1

Mean values, variability ranges and variation coefficients $(\mathrm{CV})$ of major useful traits in winter triticale genetic resources accessions

\begin{tabular}{lccccc}
\hline \multicolumn{1}{c}{ Examined trait } & $\begin{array}{c}\text { Years of } \\
\text { research }\end{array}$ & $\begin{array}{c}\text { Number of } \\
\text { objects }\end{array}$ & Mean & $\begin{array}{c}\text { Variability range } \\
\min -\max \end{array}$ & CV (\%) \\
\hline \multirow{3}{*}{ Plant height $(\mathrm{cm})$} & $1982-1990$ & 565 & 128.5 & $75.0-168.8$ & 13.8 \\
& $1991-2000$ & 561 & 106.1 & $70.0-172.0$ & 13.1 \\
& $2001-2010$ & 203 & 111.0 & $70.7-155.5$ & 11.7 \\
\hline \multirow{3}{*}{ Number of grains per spike } & $1982-1990$ & 565 & 47.1 & $19.1-79.9$ & 23.4 \\
& $1991-2000$ & 561 & 51.7 & $14.0-81.2$ & 18.9 \\
& $2001-2010$ & 203 & 46.2 & $16.4-85.1$ & 18.2 \\
\hline \multirow{2}{*}{ Weight of grains per spike $(\mathrm{g})$} & $1982-1990$ & 565 & 2.3 & $0.8-4.3$ & 27.1 \\
& $1991-2000$ & 561 & 2.7 & $0.5-6.8$ & 21.4 \\
& $2001-2010$ & 203 & 2.2 & $0.4-4.2$ & 21.5 \\
\hline \multirow{3}{*}{ 1000 grain weight $(\mathrm{g})$} & $1982-1990$ & 565 & 49.7 & $28.6-66.0$ & 15.2 \\
& $1991-2000$ & 561 & 50.1 & $28.3-86.2$ & 11.1 \\
Grain protein content $(\%)$ & $2001-2010$ & 203 & 47.4 & $25.4-83.7$ & 12.6 \\
\hline
\end{tabular}

\section{DISCUSSION}

The existence of wide genetic variation with respect to yield and other agronomic traits in a plant population is important for an effective breeding program. Development of high-yielding cultivars requires information on the magnitude of variability present in the germplasm $[2,16]$. Directional selection in breeding resulted in obtaining materials whose useful traits were more similar $[9,12-15]$. The results obtained in our work were similar to those obtained by $\mathrm{K} \mathrm{o} \mathrm{c} \mathrm{i} \mathrm{u} \mathrm{b} \mathrm{a}$ $[9,10]$ and K o c i u b a et al. $[11,17]$. They show that the highest variation coefficients were observed for the number (CV from 18.5 to $23.4 \%$ ) and weight of grains per spike (CV from 21.4 to $27.1 \%$ ). It should be remembered that a higher percentage of winter triticale genotypes with a larger number and weight of grains per spike is a result of producing valuable materials by breeders in Poland and abroad. Therefore, valuable genotypes are the ones in which the value of the trait in question exceeds $60 \mathrm{~g}$. The above-mentioned authors indicate that in winter triticale germplasm of the Polish cultivars one could select valuable initial material useful in recombination breeding for yield improvement [17-24].

Recently, a significant progress has been made in triticale breeding; this progress is shown by an increase in yield per unit of area and better seed fill, 
which can be significantly improved by systematic breeding and heavy selection pressure. Modern triticale cultivars have the potential to be competitive in terms of grain yield with wheat under optimal growing conditions. In commercial production, where triticale cultivars are mainly grown under suboptimal or stress conditions, they are generally superior to wheat and rye. However, such one-directional selection caused a decrease in total protein content in grain. The high protein content of the early materials of triticale was a result of shrivelled grain. As a consequence of increased plumpness, the protein content in grain decreased [1]. The state-sponsored research on cultivar assessment has shown that the protein content in grain of currently cultivated winter triticale cultivars is comparable to that of wheat and rye [20,21, 23, 24].

The first collection materials of winter triticale were characterized by a plant height between 140 and $160 \mathrm{~cm}$ and plants were susceptible to lodging. By introducing a partially dominant dwarfing gene from the wheat cultivar Tom Pouce, the semi-dwarf cultivar Bókoló was developed in Hungary [1]. Also in Poland this kind of cultivars was obtained. Fidelio was the first Polish semi-dwarf cultivar of winter triticale registered in 1997. The breeding programs allowed the next following semi-dwarf cultivars to be registered: Pinokio (1997), Magnat (2000), Woltario (2000), Zorro (2002), Baltiko (2006), Gniewko (2006), Grenado (2007), Alekto (2008), Borwo (2008), Pigmej (2008), Atletico (2009), Agostino (2011), Mikado (2011), Twingo (2012), and Wiarus (2012), whose plant height is below $120 \mathrm{~cm}$, which results in a significant improvement in their resistance to lodging [24].

One of the most important problems in plant breeding is the resistance to fungal diseases $[9,25$, 26]. For many years, triticale was believed to be one of the most resistant genera of crop plants and its resistance to diseases, especially to fungal diseases, was one of its main good points [25-30]. However, with the expansion of the triticale-growing area, the favorable disease resistance of the earlier genotypes changed [1]. Recently, increasingly more triticale genotypes have been affected by diseases, mainly powdery mildew (Blumeria graminis) and brown rust (Puccinia recondita). According to S trze m bi cka [31] and $\mathrm{Cza}$ jow ski et al. [32], brown rust, which has appeared in large quantities in some regions recently, may pose a serious threat to triticale cultivation because some genotypes are appropriate hosts for this pathogen. Also yellow rust, which occurs less frequently in our climate than brown rust, may pose some threat to triticale. However, Zamorski and Schollenberger [33] inform that triticale cultivars are affected by yellow rust to a smaller degree than wheat cultivars. S c h in k e 1 [34] evaluated the disease scores of the winter triticale genotypes tested in the German National Trials during 1988-2001 and compared them with wheat and rye. The obtained results show that triticale is still less susceptible to most diseases than wheat and rye, but has a similar disease spectrum. The main disease was Stargonospora (Septoria) leaf blotch. On the basis of longterm assessment, it is possible to claim that in field conditions winter triticale collection resources manifest a high resistance to powdery mildew and brown rust. This mostly concerns the genotypes examined at the initial stage of the collection $[25,26]$.

\section{CONCLUSIONS}

1. The presented results indicate that the genetic resources of winter triticale represent a wide spectrum of variability of agricultural traits. The large diversity of the examined accessions mostly relates to traits such as plant height, number and weight of grains per spike, and grain protein content.

2. Moreover, the accessions of winter triticale collected during the first years of the experiments (198290) showed a greater variability of the traits under study than the accessions collected recently. It is most probably connected with directional selection used in breeding. The older accessions were usually higher and they also had a higher grain protein content.

3. As far as the more recent collections of winter triticale genetic resources are concerned, a decrease in field resistance to powdery mildew, brown rust and septoriosis has been observed, but the intensity of these diseases varied over the years of the research.

\section{Acknowledgments}

The research was supported by the Polish Ministry of Agriculture and Rural Development (project: "Improving plants for sustainable AgroEcoSystems, high quality food and crop production for non-food purposes").

\section{Authors' contributions}

The following declarations about authors' contributions to the research have been made: designing the experiments: WK; field research: WK, AK; data analyses: AK, WK; comments on the manuscript: WK, AK; writing the manuscript: AK.

\section{REFERENCES}

1. Oettler G. The fortune of a botanical curiosity - Triticale: past, present and future. J. Agric. Sci. 2005; 143: 329-346. http://dx.doi.org/10.1017/S0021859605005290

2. Goyal A, Beres BL, Randhawa HS, Navabi A, Salmon DF, Eudes F. Yield stability analysis of 
broadly adaptive triticale germplasm in southern and central Alberta, Canada, for industrial end-use suitability. Can. J. Plant Sci. 2011; 91: 125-135. http://dx.doi.org/10.4141/ cjps 10063

3. Erekul O, Köhn W. Effect of weather and soil conditions on yield components and bread-making quality of winter wheat (Triticum aestivum L.) and winter triticale (Triticosecale Wittm.) varieties in north-east Germany. J. Agron. Crop Sci. 2006; 192: 452-464. http://dx.doi. org/10.1111/j.1439-037x.2006.00234.x

4. Beres BL, Harker KN, Clayton GW, Bremer E, Blackshaw RE, Graf RJ. Weed competitive ability of spring and winter cereals in the Northern Great Plains. Weed Technol. 2010; 24: 108-116. http://dx.doi.org/10.1614/wtd-09-00036.1

5. Cui Z, Carter TE, Burton JW, Wells R. Phenotypic diversity of modern Chinese and North American soybean cultivars. Crop Sci. 2001; 41. 1954-1967. http:// dx.doi.org/10.2135/cropsci2001.1954

6. Mohammadi S A, Pras an n M. Analysis of genetic diversity in crop plants - salient statistical tools and considerations. Crop Sci. 2003; 43.1235-1248. http://dx.doi. org/10.2135/cropsci2003.1235

7. Jaradat A A, Shahid M, Al-Maskri AY. Genetic diversity in the Batini barley landrace from Oman I. Spike and seed quantitative and qualitative traits. Crop Sci. 2004; 44: 304-315. http://dx.doi.org/10.2135/cropsci2004.0997

8. Banaszak Z, Marciniak K. Wide adaptation of DANKO triticale varieties. Proc of the $5^{\text {th }}$ Int. Triticale Symp. Radzików, Poland. 30 VI-5 VII 2002; Vol. I: 215 222.

9. Kociuba W. Charakterystyka zasobów genowych pszenżyta zgromadzonych w latach 1998-2005. / The characteristics of triticale gene resources ( $\times$ Triticosecale Wittmack) collected within 1998-2005. Zesz. Probl. Post. Nauk Roln. 2007; 517/1: 369-377. (in Polish)

10. Kociuba W. Charakterystyka zbiorów kolekcyjnych pszenżyta jako mieszańca międzyrodzajowego. / Characteristics of collection resources of triticale as an intergenus hybryd. Zesz. Probl. Post. Nauk Roln. 2010; 555: 237-247. (in Polish)

11. Kociuba W, Mądry W, Kramek A, Ukalski K, Studnicki M. Multivariate diversity of Polish winter triticale cultivars for spike and other traits. Plant Breed. Seed Sci. 2010; 62: 31-42. http://dx.doi.org/10.2478/v10129-01 1-0003-4

12. Kociuba W. Ocena ważniejszych cech rolniczych materiałów kolekcyjnych pszenżyta ozimego i jarego ( $\times$ Triticosecale Wittmack). / Assessment of agriculturally important features of winter and spring triticale collections $\times$ Triticosecale Wittmack. Biul. IHAR. 1992; 183: 125-133. (in Polish)

13. Ko ciuba W. Wartość ważniejszych cech krajowych i zagranicznych obiektów kolekcyjnych pszenżyta ozimego. Biul. IHAR. 1996; 200: 131-138. (in Polish)

14. Kociuba W. Wyniki oceny materiałów kolekcyjnych pszenżyta ozimego i jarego w 1996 roku. Biul. IHAR. 1998; 205: 219-227. (in Polish)
15. Ko ciuba W. Zmienność i współzależność ważniejszych cech plonotwórczych w obrębie heksaploidalnego pszenżyta ozimego $\times$ Triticosecale Wittmack. Rozprawy Naukowe Akademii Rolniczej w Lublinie. 2000; 232, pp. 74. (in Polish)

16. Thiemt EM, Oettler G. Agronomic performance of anther-derived doubled haploid and single seed descent lines in crosses between primary and secondary winter triticale. Plant Breed. 2008; 127: 476-479. http://dx.doi.org/10. 1111/j.1439-0523.2008.01498.x

17. Kociuba W, Kramek A, Doliński R. Porównanie wartości cech użytkowych krajowych odmian pszenżyta ozimego zarejestrowanych w latach 1982-2003. Zesz. Probl. Post. Nauk Roln. 2007; 517: 379-387. (in Polish)

18. Maćkowiak W, Budzianowski G, Cicha A, Cichy H, Mazurkiewicz L, Milewski G, Pajzert K, Szeląg B, Szeląg J, Woś H. Hodowla pszenżyta w Zakładzie Doświadczalnym Hodowli i Aklimatyzacji Roślin „Małyszyn”. Biul. IHAR. 1998; 205/206: 303-320. (in Polish)

19. Wolski T, Szołkowski A, Gryka J, Pojmaj MS. Obecny stan hodowli pszenżyta ozimego w DANKO. Biul. IHAR. 1998; 205/206: 289-297. (in Polish)

20. C y fe r t R. Pszenżyto ozime. Lista opisowa odmian 2007. Cz. I. Rośliny rolnicze. COBORU, Słupia Wielka. 2007; p. 89-96. (in Polish)

21. C y fert R. Pszenżyto ozime. Lista opisowa odmian 2008. Cz. I. Rośliny rolnicze. COBORU, Słupia Wielka. 2008; p. 89-97. (in Polish)

22. Czajka W, Zawierucha S. Wyniki porejestrowych doświadczeń odmianowych w woj. lubelskim. Zboża jare, zboża ozime i rzepak ozimy 2009. SDOO Cicibór, 2009; p. 33-38. (in Polish)

23. Najewski A, Tokarski P. Pszenżyto ozime. Lista opisowa odmian 2009. Cz. I. Rośliny rolnicze. COBORU, Słupia Wielka. 2009; p. 101-107. (in Polish)

24. Tokarski P. 2010. Pszenżyto ozime. Lista opisowa odmian 2010. Cz. I. Rośliny rolnicze. COBORU, Słupia Wielka, p. 94-103. (in Polish)

25. Kociuba W. Field estimation of resistance to fungal diseases in collection of spring triticale $(\times$ Triticosecale Wittmack). Genet. Pol. 1994; 35 B: 187-191.

26. Kociuba W. Field evaluation of the resistance to fungal diseases in a collection of winter triticale $(\times$ Triticosecale Wittmack). J. Appl. Genet. 1997; 38B: 97-100.

27. Arseniuk E. Triticale diseases - a review. In: Triticale: Today and Tomorrow. Red. Guedes-Pinto H, Darvey N, Carnide V.P. Kluw. Acad. Publ. Dordrecht. 1996; p. 499525. http://dx.doi.org/10.1007/978-94-009-0329-6_65

28. K o ciuba W. Polowa ocena odporności na choroby grzybowe w kolekcji pszenżyta ozimego ( $\times$ Triticosecale Wittmack). Biul. IHAR. 1990; 173/174: 83-86. (in Polish)

29. Arseniuk E, Woś E, Woźniak-Strzembicka A. Aspect of triticale diseases research in Poland. Vortr. Pflanzenzüchtg. 2000; 49: 63-72.

30. Brzozowski J, Kurowski TP, Brzozowska I. Wpływ zabiegów nawozowo-herbicydowych na stopień 
porażenia chorobami pszenżyta ozimego. Folia Univ. Agric. Stetin., Agricultura. 2000; 206(82): 25-30. (in Polish)

31. Strzembicka A. Występowanie mączniaka prawdziwego (Blumeria graminis sp.) na pszenzycie w Polsce. Konferencja naukowa: „Nauka dla hodowli roślin uprawnych", Zakopane, 29 I-2 II 2007; p. 42. (in Polish)

32. Czajowski G, Strzembicka A, Kraska K.Wirulencja populacji Puccinia triticina sprawcy rdzy brunatnej pszenicy i pszenżyta w Polsce w latach 2008-2010. / Virulence in population of Puccinia triticina, the causal agent of wheat and triticale leaf rust in Poland in 2008-2010. Biul. IHAR. 2011; 260/261: 145-153. (in Polish)

33. Zamorski C, Schollenberger M. Występowanie chorób pszenżyta w Polsce. / Occurrence of diseases of triticale in Poland. Biul. IHAR. 1995; 195/196: 197-207. (in Polish)

34. S chinkel B. Triticale - still a healthy crop? Proc. of the $5^{\text {th }}$ Int. Triticale Symp. Radzików, Poland. 30 VI-5 VII 2002; Vol. I: 157-162.

\section{Zmienność cech plonotwórczych i odporności na choroby w kolekcji zasobów genetycznych pszenżyta}

\section{Streszczenie}

Systematyczne gromadzenie materiałów kolekcyjnych pszenżyta ozimego rozpoczęto w Polsce od 1982 roku w Instytucie Genetyki, Hodowli Roślin i Nasiennictwa Akademii Rolniczej w Lublinie (obecny Instytut Genetyki, Hodowli i Biotechnologii Roślin, Uniwersytet Przyrodniczy w Lublinie). Początkowo gromadzono głównie rody hodowlane otrzymane w krajowych ośrodkach hodowli pszenżyta. Następnie sprowadzono materiały ze światowych banków genów: Beltsville, Gatersleben, VIR. Do kolekcji włączono także interesujące materiały mieszańcowe otrzymywane w placówkach badawczych. Obecnie kolekcja liczy 2349 obiektów (1329 pszenżyta ozimego i 1020 pszenżyta jarego). Ewaluacja prowadzona jest w 4-letnim cyklu doświadczeń polowych według jednolitej metodyki. Zgromadzone materiały kolekcyjne reprezentują duże spektrum zmienności zarówno cech morfologicznych, jak i użytkowych. Duże zróżnicowanie badanych obiektów kolekcyjnych dotyczy zwłaszcza takich cech, jak: wysokość roślin, liczba i masa ziarn z kłosa, zawartość białka w ziarnie oraz polowa odporność na mączniaka właściwego, rdzę brunatną oraz choroby liści i kłosów.

Handling Editor: Bogusław Sawicki

This is an Open Access digital version of the article distributed under the terms of the Creative Commons Attribution 3.0 License (creativecommons.org/licenses/by/3.0/), which permits redistribution, commercial and non-commercial, provided that the article is properly cited.

CThe Author(s) 2014 Published by Polish Botanical Society 